\title{
PLASMA PROTEINS IN TOXEMIAS OF PREGNANCY
}

\author{
BY HAROLD C. MACK \\ (From the Departments of Obstetrics and Gynecology, Harper Hospital and Herman Kiefer \\ Hospital, Detroit, Mich.) \\ AND \\ By ABNER R. ROBINSON, MARGARET E. WISEMAN, ERNEST J. SCHOEB, AND \\ ICIE G. MACY
}

(From the Research Laboratory, Children's Fund of Michigan, Detroit)

(Submitted for publication December 26, 1950; accepted, April 2, 1951)

Numerous studies of the toxemias of late pregnancy have consistently demonstrated the association of pre-eclampsia and eclampsia with disturbances of protein metabolism indicated by derangements in the protein composition of the blood. Whether these changes in themselves cause the symptoms of toxemia or are secondary to the elusive "toxic" factor has not been determined. Many circumstances are known to provide the basis for protein deficiency within the human body, by increasing the tissue requirement for protein or by interfering with assimilation and utilization of an intake which would otherwise be adequate $(1,2)$. Evidence relating to the possible relationship of nutritional disturbances to the occurrence of toxemia is contradictory (3-9). In an excellent analysis of the problem of comparing conflicting reports in the literature, Møller-Christensen and Thygesen (10) emphasized the intimate connection between changes in protein balance and accompanying shifts in water and salt balances, and suggested the possibility of derangement in function of the adrenal in protein metabolism in toxemia. A complex explanation involving the presence of a toxic protein (an atypical euglobulin) in the circulating blood during menstruation, labor, and toxemia of pregnancy has been advanced by Smith and Smith $(11,12)$.

While a relationship between disturbed protein metabolism and toxemia of pregnancy has been established, the evidence does not show that the disturbance results from dietary protein deficiency. Dieckmann (13) believes that hypoproteinemia is neither the cause of pre-eclampsia and eclampsia, nor the cause of edema. Novak and Lustig (14) caution against identification of the hypoproteinemia of pregnancy with hypoproteinemia due to malnutrition and believe that within limits it is a physiologic condition. The finding by Bibb (15) that most women who developed toxemia had some previously existing hypoproteinemia would be expected. Despite suggestive data, theories relating toxemia to nutritional deficiency fail, as do all other hypotheses advanced, to explain many features of this disorder, notably its singular predilection for the primigravida. Our increased understanding in the past few years of the importance of interrelationships among various components of the food intake may provide a key to further elucidation of the role of nutrition in toxemias of pregnancy, but it seems likely that both nutritional and physiologic factors may be involved, the number varying perhaps with still other conditions. Certainly, even with respect to the part played by well-established changes in blood proteins, eclampsia remains "the disease of theories."

The conflicting reports in the literature and the recent development of the electrophoretic technique of analysis were responsible for the decision to determine the distribution of plasma proteins in the blood of women during pregnancy, at delivery, and in the puerperium. A preceding publication (16) reported the distribution of proteins in the plasma of healthy women during the menstrual cycle, during successive stages of normal pregnancies, and postpartum, demonstrating the shifts in plasma protein composition which are characteristic of uncomplicated gestation. The same techniques were employed under comparable conditions in investigations of the protein constituents of the blood plasma of women whose pregnancies were complicated by toxemia and other gestational disturbances. The results demonstrate some of the causes of the wide variations encountered in the literature and indicate profit- 
able directions for further study. Subsequent papers will record results of determinations of plasma proteins in samples from subjects with renal and liver diseases, hypertension, diabetes, and other conditions.

\section{PROCEDURE}

This report presents the results obtained from analyses of blood samples from 29 private and clinic patients admitted to the obstetrical services of Harper Hospital and Herman Kiefer Hospital, Detroit. All were studied first in the last trimester of pregnancy after toxemia had developed. The methods of obtaining blood samples, prepa- ration, and analysis were identical with those described (16). The buffer solution (barbital) used was $0.1 \mathrm{~N}$ with respect to sodium diethylbarbiturate and $0.02 \mathrm{~N}$ with respect to diethylbarbituric acid. Electrophoretic recordings were made with a Tiselius instrument employing the Longsworth scanning mechanism and a three-piece Tiselius cell with a single, long center section. Determinations were run for three hours at $1^{\circ} \mathrm{C}$. and a potential gradient of about 6 volts $/ \mathrm{cm}$.

Appraisal of history, physical, and laboratory findings, and postpartum outcome are usually necessary to permit some degree of accuracy in evaluation. Hence, final classification of the patients was determined only after postpartum observations were available. The patients studied fell into the following categories according to the

TABLE I

Data from medical records of 29 patients with toxemias of pregnancy

\begin{tabular}{|c|c|c|c|c|c|c|c|c|c|c|c|}
\hline & \multirow{3}{*}{ Subject* } & \multicolumn{8}{|c|}{ Mother } & \multicolumn{2}{|c|}{ Infant } \\
\hline & & \multirow{2}{*}{$\begin{array}{c}\text { Age } \\
\text { (yrs.) }\end{array}$} & \multirow{2}{*}{$\frac{\text { Parity }}{\text { Gravida }}$} & \multirow{2}{*}{$\begin{array}{c}\text { Term } \\
\text { gestation } \\
(w k s .)\end{array}$} & \multicolumn{2}{|c|}{ Blood pressure } & \multirow{2}{*}{$\begin{array}{c}\text { Albu- } \\
\text { minuria }\end{array}$} & \multirow{2}{*}{ Edema } & \multirow{2}{*}{$\begin{array}{l}\text { Total weight } \\
\text { gain during } \\
\text { pregnancy } \\
\text { (lbs.) }\end{array}$} & \multirow{2}{*}{ Sex } & \multirow{2}{*}{$\begin{array}{l}\text { Weight } \\
(\mathrm{gm.} .)\end{array}$} \\
\hline & & & & & $\begin{array}{l}\text { When } \\
\text { admitted }\end{array}$ & $\begin{array}{c}\text { Post- } \\
\text { partum† }\end{array}$ & & & & & \\
\hline $\begin{array}{l}\text { Mild pre- } \\
\text { eclampsia }\end{array}$ & $\begin{array}{c}3 \\
18 \\
27 \\
44 \\
47 \\
52 \ddagger \\
53 \\
73 \\
78 \\
108 \\
118 \\
123\end{array}$ & $\begin{array}{l}31 \\
18 \\
26 \\
25 \\
24 \\
41 \\
26 \\
26 \\
23 \\
34 \\
26 \\
28\end{array}$ & $\begin{array}{l}1 / 1 \\
1 / 1 \\
2 / 3 \\
1 / 1 \\
1 / 1 \\
1 / 5 \\
1 / 1 \\
1 / 2 \\
1 / 1 \\
1 / 1 \\
1 / 2 \\
2 / 2\end{array}$ & $\begin{array}{l}42 \\
42 \\
41 \\
37 \\
40 \\
38 \\
42 \\
40 \\
35 \\
41 \\
35 \\
41\end{array}$ & $\begin{array}{l}164 / 100 \\
170 / 120 \\
140 / 100 \\
154 / 104 \\
144 / 90 \\
174 / 90 \\
155 / 80 \\
180 / 100 \\
146 / 104 \\
160 / 90 \\
174 / 120 \\
152 / 92\end{array}$ & $\begin{array}{l}125 / 70 \\
142 / 90 \\
132 / 80 \\
120 / 70 \\
108 / 60 \\
160 / 100 \\
122 / 80 \\
150 / 90 \\
105 / 70 \\
120 / 70 \\
120 / 90 \\
120 / 90\end{array}$ & & & $\begin{array}{l}15 \\
44 \\
22 \\
24 \\
34 \\
38 \\
43 \\
28 \\
22 \\
50 \\
30 \\
23.5\end{array}$ & $\begin{array}{l}\mathbf{M} \\
\mathbf{F} \\
\mathbf{M} \\
\mathbf{M} \\
\mathbf{F} \\
\mathbf{F} \\
\mathbf{M} \\
\mathbf{F} \\
\mathbf{F} \\
\mathbf{F} \\
\mathbf{F} \\
\mathbf{F}\end{array}$ & $\begin{array}{l}3005 \\
3288 \\
3827 \\
2282 \\
3714 \\
3118 \\
3487 \\
3856 \\
1502^{* *} \\
3062 \\
1474 \\
3799\end{array}$ \\
\hline $\begin{array}{l}\text { Severe pre- } \\
\text { eclampsia }\end{array}$ & $\begin{array}{c}4 \\
17 \S \\
24 \| \\
31 \| \\
32 \\
37 \\
\\
87 \| \\
94 \\
107 \| \\
169 \\
170 \\
171\end{array}$ & $\begin{array}{l}19 \\
37 \\
\\
18 \\
35 \\
38 \\
23 \\
\\
20 \\
\\
29 \\
26 \\
35 \\
41 \\
26\end{array}$ & $\begin{array}{l}1 / 1 \\
4 / 4 \\
1 / 1 \\
2 / 3 \\
3 / 3 \\
1 / 2 \\
\\
1 / 1 \\
\\
1 / 1 \\
3 / 5 \\
1 / 2 \\
2 / 4 \\
0 / 1\end{array}$ & $\begin{array}{l}39 \\
32 \\
\\
39 \\
37 \\
39 \\
43 \\
\\
38 \\
\\
35 \\
30 \\
34 \\
38 \\
35\end{array}$ & $\begin{array}{l}184 / 100 \\
155 / 90 \\
\\
162 / 118 \\
190 / 100 \\
180 / 110 \\
170 / 110 \\
190 / 120 \\
180 / 120 \\
190 / 120 \\
198 / 100 \\
190 / 110 \\
170 / 100\end{array}$ & $\begin{array}{l}112 / 78 \\
138 / 90 \\
124 / 80 \\
150 / 90 \\
115 / 75 \\
146 / 104 \\
130 / 88 \\
138 / 90 \\
140 / 90 \\
130 / 90 \\
145 / 95 \\
132 / 70\end{array}$ & & & $\begin{array}{l}37 \\
53 \\
21 \\
23 \\
8 \\
22 \\
31 \\
10 \\
\frac{10}{20} \\
12.5 \\
36\end{array}$ & $\begin{array}{l}\mathbf{F} \\
\mathbf{M} \\
\mathbf{M} \\
\mathbf{M} \\
\mathbf{F} \\
\mathbf{F} \\
\mathbf{F} \\
\mathbf{M} \\
\mathbf{F} \\
\mathbf{M} \\
\mathbf{F} \\
\mathbf{F} \\
\mathbf{F} \\
\mathbf{F} \\
\mathbf{M}\end{array}$ & $\begin{array}{l}3090 \\
1502^{* *} \\
1361^{* *} \\
2268 \\
2070 \\
1928 \\
2041 \\
2665 \\
2948 \\
2466 \\
992^{* *} \\
3175^{* *} \\
1502 \\
1602 \\
2211^{* *}\end{array}$ \\
\hline Eclampsia $\mathbb{T}$ & $\begin{array}{r}2 \| \\
14 \\
64 \| \\
82 \\
111 \|\end{array}$ & $\begin{array}{l}18 \\
26 \\
36 \\
23 \\
18\end{array}$ & $\begin{array}{l}1 / 1 \\
1 / 1 \\
6 / 7 \\
1 / 1 \\
1 / 1\end{array}$ & $\begin{array}{l}38 \\
35 \\
42 \\
33 \\
35\end{array}$ & $\begin{array}{l}180 / 120 \\
140 / 110 \\
215 / 115 \\
160 / 100 \\
160 / 110\end{array}$ & $\begin{array}{l}160 / 110 \\
110 / 64 \\
130 / 90 \\
130 / 80 \\
122 / 70\end{array}$ & & + & $\begin{array}{l}13 \\
13 \\
60 \\
37\end{array}$ & $\begin{array}{l}\mathbf{F} \\
\mathbf{M} \\
\mathbf{F} \\
\mathbf{M} \\
\mathbf{M}\end{array}$ & $\begin{array}{l}3260 \\
1502 \\
3969 \\
2495 \\
2098\end{array}$ \\
\hline
\end{tabular}

* Subjects 4, 18, 31, 37, 107, 170, and 171 are negroes; subject 47 is Mongolian.

Approximately six weeks.

$\$$ Four previous spontaneous abortions; stilbestrol therapy during pregnancy.

Rh negative-high titer. sive.

No prenatal care. Abruptio placentae occurred with subjects 24, 107, and 171. Subject 31 previously was hyperten-

I Convulsions occurred three times with subject 2; twice with each of the other patients.

** Stillborn. 
clinical classification proposed in 1939 by the American Committee on Maternal Health: mild pre-eclampsia, 12 cases; severe pre-eclampsia, 12 cases; eclampsia, five cases. Pertinent information from the clinical histories of the patients is summarized in Table I.

\section{RESULTS AND DISCUSSION}

The means and ranges of concentrations of total protein and protein fractions in the plasma of blood obtained prepartum, at delivery, and postpartum are given in Table II. The results, insofar as can be determined, were not influenced by any form of therapy prior to the time of blood sampling. ${ }^{1}$ The distribution of the total protein among the protein fractions and the albumin/globulin ratios are given in Table III. Values for women whose pregnancies were uncomplicated (normal) and for non-pregnant women (16) are included for comparison. Individual values for each woman will be presented in a subsequent report.

Numerous publications $(10,13,14,18-22)$ have given the quantities of proteins in the blood in normal and toxemic pregnancies, based for the most part on the results of various salt fractionation technics. All agree on the general pattern of the changes in the blood proteins, described as "dyscolloidosis" by Seitz (19) and Eufinger (20) although the degree of alteration in toxemia and the clinical significance of these changes are variously interpreted. All agree that a definite hypoproteinemia, greater than that observed in normal pregnancy, is found in the toxemias. Since the technics employed differ, and more especially, since there is no uniformity with which the various clinical types and degrees of toxemia are classified, protein values reported cannot be compared directly.

In the preceding paper (16) we compared electrophoretic results in normal pregnancies and postpartum with those for healthy non-pregnant women. The data showed that by six to 12 weeks postpartum (average, eight weeks) "the return of the plasma protein pattern toward normal is almost complete. ..." If in healthy women whose preg-

\footnotetext{
1 In one patient, stilbestrol therapy as recommended by Smith (17) was employed in regularly increasing amounts (up to $125 \mathrm{mg}$. daily) from the seventh to the thirty-fifth neek of gestation to prevent abortion. Despite continuous estrogen therapy and normal hormone excretion this patient developed mild pre-eclampsia, with electrophoretic patterns similar to those of other subjects with the same type of toxemia.
}

nancies have been uncomplicated, the levels of blood proteins five to six days postpartum are significantly different from non-pregnant values and have not completely returned to normal levels by eight weeks postpartum, on the average, it seems evident that accurate control data for women who have had toxemias of pregnancy cannot be obtained from the same subjects sooner than eight or more weeks following delivery.

In pre-eclampsia and eclampsia mean concentrations (Table II) in plasma of total protein, albumin, beta and gamma globulins tended to be lower than comparable values in normal pregnancy. The other globulin fractions showed trends dissimilar to those of total protein, albumin, and gamma globulin, with a tendency for values to be higher than in normal pregnancy.

In normal pregnancy mean values for fibrinogen (phi globulin) in the third trimester were higher than the average for non-pregnant women, showed little change at delivery and five or six days postpartum, and declined to below non-pregnant levels by six to 12 weeks postpartum. In pre-eclampsia a similar trend occurred at a somewhat higher level, with levels six to 12 weeks postpartum approximating the average for non-pregnant women. In eclampsia, however, the means before and at delivery were higher than that of any other group, at one to five days postpartum the average still was high, and six to 12 weeks postpartum the mean was higher than that of nonpregnant women. Both chemical and electrophoretic determinations of fibrinogen have disclosed levels in toxemia even higher than the recognized increase in normal pregnancy. According to Dieckmann (13), a falling fibrin level in eclampsia implies a grave prognosis, and Dillon and Schmitz (23) reported two instances of fatal fibrinogenopenia in eclampsia. Among the cases of severe pre-eclampsia for which data are reported in this paper were three in which premature placental separation occurred. For these three patients, plasma fibrinogen levels were lower than those of patients in whom this complication did not occur. The levels, however, were not lower than mean values in uncomplicated pregnancy.

In a consideration of blood proteins in the toxemias of pregnancy two trends must be evaluated in relation to concomitant manifestations of disturbed physiologic function: their relation (1) to levels 


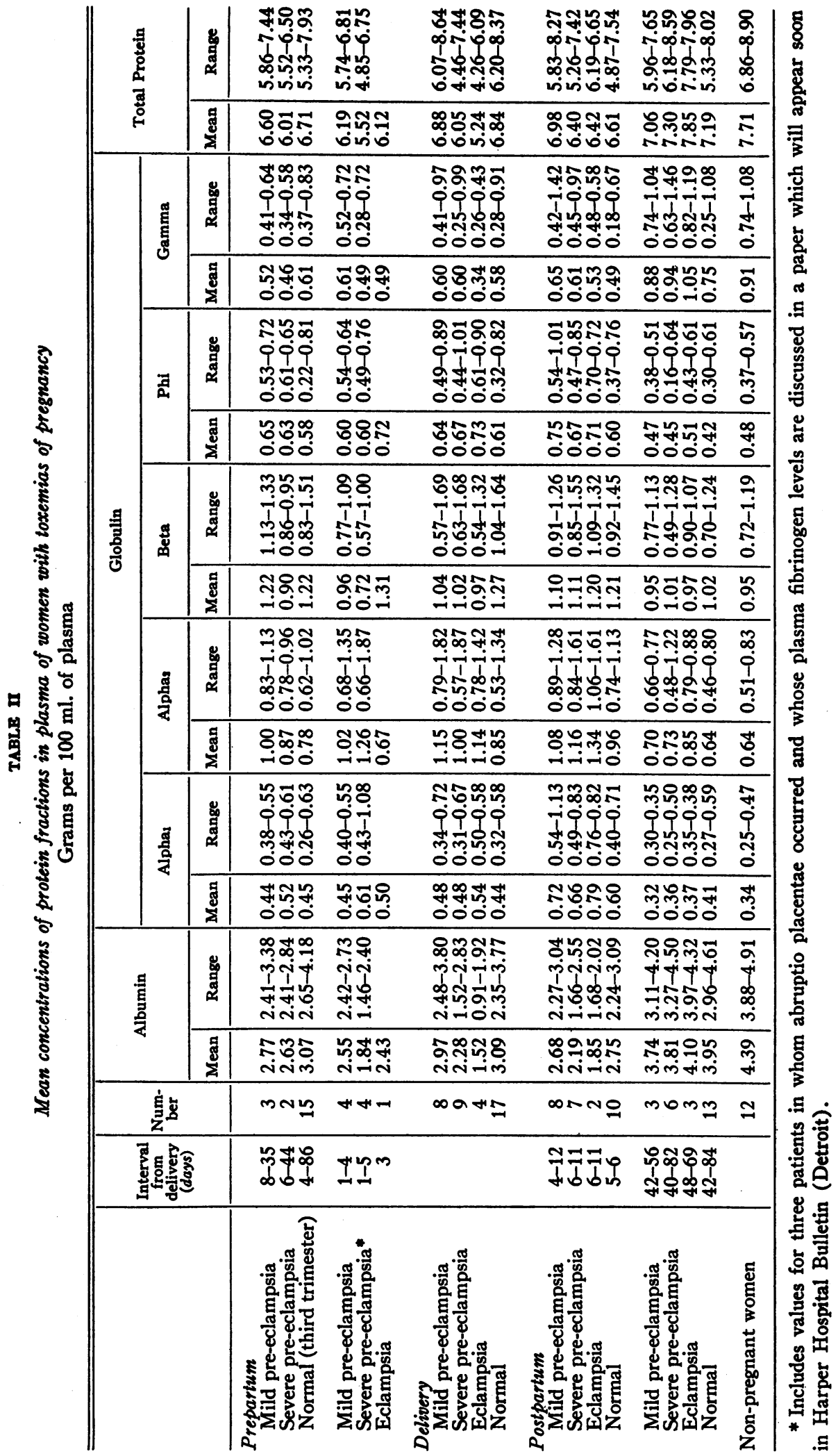


PLASMA PROTEINS IN PREgNANCY TOXEMIAS

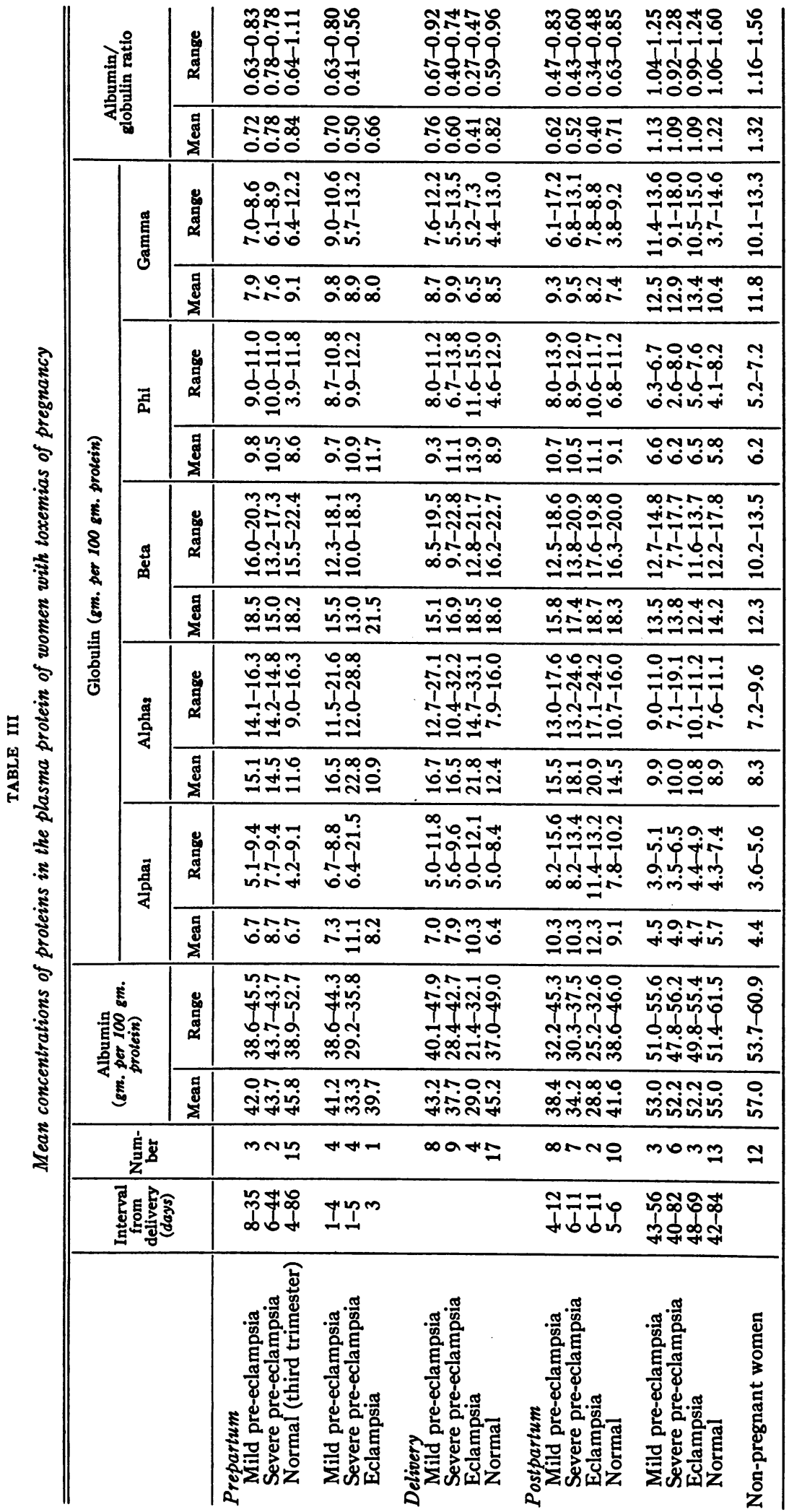


and trends in normal pregnancy and (2) to levels in healthy non-pregnant women. Heretofore, comparable data have not been available which would permit comparison of the trends from prepartum to recovery in eclampsia with the trends in normal pregnancy or the comparison of trends of protein concentrations in mild and severe preeclampsia at different times in relation to delivery with values in normal pregnancy and for non-pregnant women. Undoubtedly, in addition to differences in method of sampling and analysis the previous lack of values for various intervals preand postpartum, both in normal and complicated pregnancies, has been responsible in large measure for discrepant results in the literature. The progressively severe clinical picture described as mild pre-eclampsia, severe pre-eclampsia, and eclampsia suggests a progressive change in accompanying internal conditions in the body. The data in Tables II and III show that such parallelism does not hold true for all protein fractions and for all times in relation to delivery. Likewise, the protein values accompanying increased severity of the clinical picture do not consistently increase or decrease in relation to comparable values for normal pregnant women.

From the data in Table II it is readily understandable that Lagercrantz (24) found a decline in total protein and albumin during the last month of gestation but with values no lower than those for normal pregnancy in his group of unassorted patients with various types and degrees of toxemia. Our study shows, on the contrary, little change in the mean quantities of total protein and albumin from the third trimester to delivery in normal pregnancy (Table II). Thus, with a mean of normal values within a lower range than that found in our study, or with a mean for toxemia which by chance represented subjects whose levels ranged higher for their degree of toxemia, it is understandable that similar or even higher than normal levels might be found in other series of toxic women. Thus, also, the possible lowering of total protein levels in eclampsia during the five days immediately prepartum would be obscured and as well, the trends we have observed toward lower concentration of total protein and albumin with increased severity of pre-eclampsia.

Whether the lowered plasma protein concentrations in toxemia actually represent a real loss of protein supplies in the body can be determined only by measurements of blood and plasma volume, for which precise methods are not available. Studies of blood volume in pregnancy (25) have consistently shown an increase of plasma volume of approximately 25 per cent subject, however, to great individual variations. In the evaluation of differences in protein concentration and distribution between women with and without toxemia the question is not whether blood volume increases during gestation but, rather, whether the increase varies when toxemia occurs. Since rapid changes in water balance occur in toxemia, deductions based on averages of a few values are especially subject to error and valid conclusions can be reached only with results for a large number of women or by following the same patients at frequent intervals, especially late in gestation and early in the puerperium. The data obtained in this investigation emphasize that confirmation or refutation of the numerous speculations which have been advanced will require more detailed study of accurately defined groups, both normal and abnormal, at more frequent intervals, and with comparable methods.

The data strongly suggest that the eclamptogenic syndrome is accompanied by alterations in the plasma proteins which represent a modification of changes which are physiologic in pregnancy. The deviations from normal in pre-eclampsia during the third trimester of pregnancy indicate that changes in the amounts and distribution of the plasma proteins may antedate the appearance of clinical signs and symptoms of toxemia. However, no evidence was obtained of a relationship to dietary protein inadequacy before or during pregnancy. The fact that the eclamptogenic effects in the third trimester, notably the increases in fibrinogen and the alpha ${ }_{2}$ globulins and the decreases in gamma globulin and albumin, occurred on the basis of percentages of total protein as well as in terms of plasma demonstrates that the alterations are not reflections of changes in blood volume.

\section{SUMMARY}

The electrophoretic method is being used to study the plasma protein prepartum, at delivery, and postpartum in the blood of women whose pregnancies are normal, and those whose pregnancies 
are complicated by toxemia, renal disease, hypertension, diabetes and other gestational disturbances. Means and ranges for total protein, albumin, and alpha $a_{1}$ alpha $a_{2}$, beta, gamma, and phi globulins are presented for 29 women who had mild eclampsia, severe pre-eclampsia, or eclampsia before delivery.

The results stress the need for determinations at narrower and more sharply defined intervals prepartum and postpartum for larger groups of patients carefully grouped according to diagnostic criteria and according to the severity of clinical symptoms.

Determinations of plasma proteins for nonpregnant women and for normal pregnant women and patients with toxemia at intervals of a few days and six to 12 weeks postpartum emphasize that normal non-pregnant levels of plasma proteins are not achieved for several weeks after delivery and determinations as early as ten days or two weeks postpartum do not provide adequate "control" data.

\section{REFERENCES}

1. Strauss, M. B., Observations on the etiology of the toxemias of pregnancy. The relationship of nutritional deficiency, hypoproteinemia, and elevated venous pressure to water retention in pregnancy. Am. J. M. Sc., 1935, 190, 811.

2. Stare, F. J., and Thorn, G. W., Protein nutrition in problems of medical interest. J.A.M.A., 1945, 127, 1120.

3. Siddall, A. C., Vitamin $B_{1}$ deficiency as an etiologic factor in pregnancy toxemias; preliminary communication. Am. J. Obst. \& Gynec., 1938, 35, 662.

4. Ross, R. A., Perlzweig, W. A., Taylor, H. M., McBryde, A., Yates, A., and Kondritzer, A. A., A study of certain dietary factors of possible etiologic significance in toxemias of pregnancy. Am. J. Obst. \& Gynec., 1938, 35, 426.

5. Whitacre, F. E., Loeb, W. M., Jr., and Chin, H., A contribution to the study of eclampsia. Consideration of 200 cases. J.A.M.A., 1947, 133, 445.

6. Mastboom, J. L., Frequency of eclampsia in wartime. Nederl. tijdschr. v. geneesk., 1948, 92, 3604.

7. ten Berge, B. S., Protein therapy in eclampsia. Nederl. tijdschr. v. geneesk., 1948, 92, 2378.

8. Smith, C. A., Effect of wartime starvation in Holland upon pregnancy and its product. Am. J. Obst. \& Gynec., 1947, 53, 599.

9. Kooser, J. H., Observations on the possible relationship of diet to the late toxemia of pregnancy. Am. J. Obst. \& Gynec., 1941, 41, 288.
10. Møller-Christensen, E., and Thygesen, J. E., Investigation of the serum-protein balance in normal and toxemic pregnant women. J. Obst. \& Gynaec. Brit. Emp., 1946, 53, 328.

11. Smith, O. W., and Smith, G. V. S., A fibrinolytic enzyme in menstruation and late pregnancy toxemia. Science, 1945, 102, 253.

12. Smith, O. W., and Smith, G. V. S., Evidence for circulating menstrual "toxin" during menstruation and toxemia of late pregnancy. Proc. Soc. Exper. Biol. \& Med., 1945, 59, 119.

13. Dieckmann, W. J., The Toxemias of Pregnancy. The C. V. Mosby Co., St. Louis, 1941.

14. Novak, J., and Lustig, B., Quantitative and qualitative changes of the serum proteins in normal and toxemic pregnancy. The nature of the hypoproteinemia in pregnancy. J. Mt. Sinai Hosp., 1947, 14, 534.

15. Bibb, J. D., Protein and hemoglobulin in normal and toxic pregnancies. Am. J. Obst. \& Gynec., 1941, 42, 103.

16. Coryell, M. N., Beach, E. F., Robinson, A. R., Macy, I. G., and Mack, H. C., Metabolism of women during the reproductive cycle. XVII. Changes in electrophoretic patterns of plasma proteins throughout the cycle and following delivery. J. Clin. Invest., $1950,29,1559$.

17. Smith, O. W., Diethylstilbestrol in the prevention and treatment of complications of pregnancy. Am. J. Obst. \& Gynec., 1948, 56, 821.

18. Plass, E. D., and Bogert, L. J., Plasma protein variations in normal and toxemic pregnancies. Bull. Johns Hopkins Hosp., 1924, 35, 361.

19. Seitz, L., Biologie der Placenta; pathologischer Teil; die pathologische Biologie der Placenta und die wichtigsten chemisch-physikalischen und biologischen Grundlagen der Schwangerschaftstoxikosen. Arch. f. Gynäk., 1929, 137, 322.

20. Eufinger, H., Die kolloidstruktur des Plasmas während der Gestation. I. Die Kolloidstabilität des Plasmas während der normalen Gestationsperiode. Arch. f. Gynäk., 1928, 133, 452.

21. Eastman, N. J., The serum proteins in the toxemias of pregnancy. Am. J. Obst. \& Gynec., 1930, 19, 343.

22. Rinehart, R. E., Serum protein in normal and toxemic pregnancy. Am. J. Obst. \& Gynec., 1945, 50, 48.

23. Dillon, W. F., and Schmitz, H. E., Fulminating eclampsia associated with fibrinogenopoenia and hemorrhage. Illinois M. J., 1949, 96, 255.

24. Lagercrantz, C., Electrophoretic analysis of serum in pregnancy and in pregnancy toxemia. Upsala läkaref. förh., 1945, 51, 117.

25. Dieckmann, W. J., and Wegner, C. R., Studies of the blood in normal pregnancy. III. Hemoglobin and cell volume co-efficients; erythrocyte volume, hemoglobin content and concentration; color, volume and saturation indexes. Arch. Int. Med., 1934, 53, 345. 